\title{
Green Factory Planning
}

\section{Framework and Modules for a Flexible Approach}

\author{
Florian Mueller ${ }^{1}$, Alessandro Cannata ${ }^{1}$, Bojan Stahl $^{2}$, Marco Taisch $^{2}$, \\ Sebastian Thiede ${ }^{3}$, and Christoph Herrmann ${ }^{3}$ \\ ${ }^{1}$ Siemens AG Corporate Technology, CT PPC PPO IFP, München, Germany \\ \{muellerflorian.ext, alessandro.cannata\} @siemens.com \\ ${ }^{2}$ Departimento di Ingegneria Gestionale, Politecnico di Milano, Milan, Italy \\ \{bojan.stahl, marco.taisch\} @polimi.it \\ ${ }^{3}$ Institute of Machine Tools and Production Technology, \\ Technische Universität Braunschweig, IWF, Braunschweig, Germany \\ \{s.thiede, c.herrmann\} atu-braunschweig.de
}

\begin{abstract}
Planning green factories implies increased complexity depending on specific planning requirements and contradictory planning targets; these aspects challenge present methods and tool for factory planning. To properly face these challenges with limited time and resources (typical of planning projects), a factory planning approach that particularly addresses green has to be adaptable to specific cases and aligned with the green vision of the factory. This paper proposes a modular Green Factory Planning and describes its main components. The conceptual elements for a framework and a planning process are presented and differences in methods and tool applications are described in comparison to established approaches. The method and tools are combined to planning modules, linked with a clear information flow as well as responsibility definition. A use case for a typical module that specifically considers energy consumption shows the potential of green as integrated vision for factory planning.
\end{abstract}

Keywords: Factory Planning, Green Factory Planning, Energy Efficiency, Sustainable Factory, Modular Planning.

\section{Motivation}

The scarcity of resources and the use-related environmental impact of production created a new ecological challenge with economic impacts for industrial companies. Starting with the reactive measures for the end use of products (i.e. recycling) the awareness for resource consumption moved into more proactive consideration within product design, production operation and also factory planning. This challenged existing principles and approaches and required new ways of thinking.

The term 'green' is often used for exploitation of energy and resource efficient production. Even if there is no widely accepted definition of 'green' and 'green factory' available, the common understanding is to provide more economical value with minimized effects on the ecological surrounding. Definitions like 'sustainability' [1], 
'eco-efficiency' [2] or 'green production' [3] are considered in this paper to create an individually applicable framework and vision for green factory planning.

Hence 'green' as planning target should be identified individually within several borders (e.g. ROI accepted, environmental influences considered) to achieve company wide acceptance. Existing factory planning approaches that consider the effect on the environment are mainly focused on energy efficiency as defined in formula (1):

$$
\frac{\text { Net production value }}{\text { primary energy consumption }}=\frac{€}{\mathrm{kWh}}
$$

From the descriptive point of view, green measures and methods are added to standardized establish factory planning approaches, e.g. Mueller et al. [4] uses the standard process of factory planning by the German society of engineers (VDI) [5]. 'Green' is seen as add-on to a general planning process and is mainly executed by applying a list of different measures to improve energy efficiency. Interactions of several measures to improve energy efficiency are not integrated in the planning task but need to be calculated iteratively. An alignment of all planning activities to this goal is missing.

On top, several other trends like lean production, transformation ability or IT integration changed the approach factory planning is executed [6]. Additional targets increased complexity and required expertise for the factory planner, while the available time and resources for factory planning projects decreased because of increased speed of market change. To overcome this, standardized step-by-step factory planning approaches were redesigned to be more case specific and adaptable to changing requirements. By making planning activities modular, planning time can reduced by parallelized work among different disciplines (e.g. production planner and architect) and the focus on most important activities for the specific case [7].

\section{Overview Green Factory Planning}

Industrial challenges, i.e. 'green' as fully integrated in factory planning and a modular planning approach, led to the definition of 'Green Factory Planning' described here. This research was developed within the framework of the European research project 'EMC'2-Factory' (www.emc2-factory). The authors argue that we cannot address challenges of green factory planning by solely adding energy efficiency as additional goal to existing planning approaches, because synergies from energy perspective are weakly addressed. A green factory for automotive with highly automated processes is different from a train production with mainly manual processes for example, because the energy consumption of the equipment is more relevant in the automotive case.. Moreover, every factory has its own main distinguishing drivers for energy efficiency (e.g. dimensioning of machines or TBS optimization). Consequently, each factory should be planned uniquely, by selecting and addressing its specific energy drivers.

A first attempt for an adaptable planning process considering environmental aspects has been done [8]. Effects of factory elements are linked with their effects on the environment, so an overview of interactions among each other is provided. 
Nevertheless, the approach is focused on impact evaluation and has no broad view on other planning aspects. The execution of other planning tasks is not extensively addressed. A comprehensive factory planning consists of four components (see Fig. 1) as suggested from the comparison of several planning approaches (see for example [9]):

1. A clear vision and a framework, where underlying targets of factory planning project are defined and the content and decisions for the factory planning are distinguished. The framework links management with planning activities and aligns the whole process to general fields of action.

2. The planning process, that provides the general order of planning tasks (e.g. detailed definition after rough definition), the decision making flow and project management integration. In most approaches a straightforward step by step process is used. But to ensure green integration and adaptability to specific cases, a process based on independent modules with guided interactions among them has been chosen. For the content of planning environmental-conscious, some planning tasks have to be redefined, integrated and conducted by different planning disciplines. Timeframe and methods for evaluation and decision making have to be rethought.

3. Definition and description of applicable methods that can be used to fulfill the planning tasks. Within these components the work is performed, information generated and responsibilities defined.

4. Tools that support the execution of planning methods. Especially in data processing, decision preparation and evaluation of alternatives the use of tools, from highly sophisticated software up to simple checklists, is recommended.

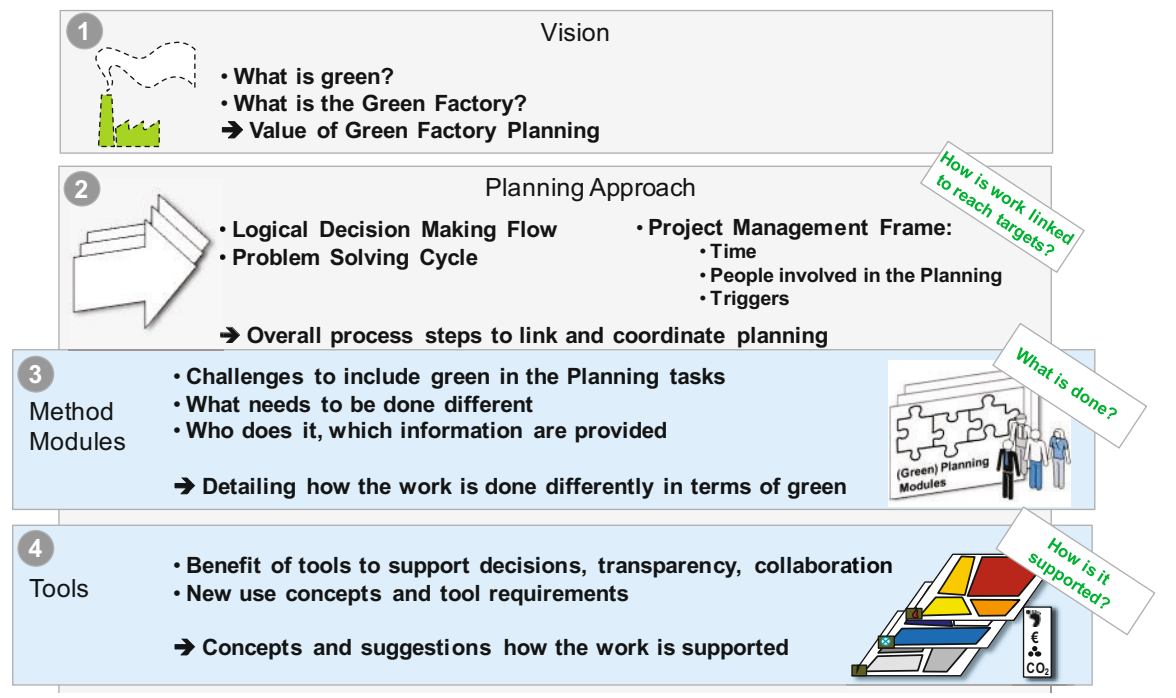

Fig. 1. Elements of Green Factory Planning

The framework and vision bring general guidance and specific planning targets while the process defines the order of method modules (timeline) and its information 
input-output relations. To ensure case-specificity and adaptability, the work that needs to be performed during factory planning is encapsulated into planning modules.

To identify the modules that need to be conducted specifically 'green', a target planning method based on a factory morphology is developed (1) (see overview in Fig. 2). The target definition is mandatory to set clear targets and decide on green/conventional modules. Objective factory features are analyzed with subjective planning targets to prioritize the most relevant drivers for energy efficiency. Based on the prioritization, factory-specific green modules can be chosen (2). To allow for an integrated perspective during the multi-disciplinary factory planning, a methodic evaluation is continuously provided for every decision that needs to be made (3). The evaluation is based on a layer visualization concept, that represents energy and production related indicators (e.g. temperature, consumed energy) with a multiperspective view on the layout to make the high variety of interacting aspects visible. The planning modules are linked to a logical timeline (4) considering the involvement of different experts (5). A detailed description of prioritization and the work flow is given in [10].

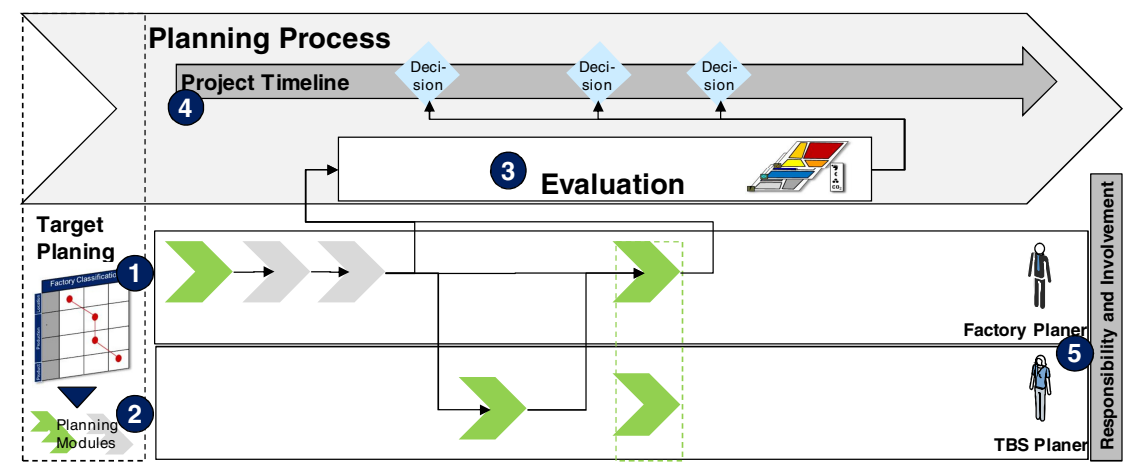

Fig. 2. Green Factory Planning Process

While all four elements of the concept are relevant for factory planning and project organization, the project-specific work is performed during the method modules with use of supporting tools. Examples of modules are described in the following chapter.

\section{Conventional and Green Factory Planning Modules}

Modules are defined based on systems engineering principles, e.g. object-orientation [7]. They are activity oriented entities that are well-defined and connected over information relations. Every module is dedicated to one or more responsible disciplines. The planning modules are covering descriptions of tasks to be done and the proceeding how to do, a set of possible tools to support and the people that need to be involved in the module. To make modules independently usable for different disciplines involved in the Green Factory Planning, interactions between the planning modules are defined over a clear information flow with input-output restrictions. 
To be comprehensive, the factory planning process considers green planning modules or conventional planning modules. Conventional planning modules cover tasks that are not as relevant for establishing a green factory in the specific case; hence they are done with methods and tools that don't have an additional focus on 'green'. Green modules on the other hand can combine or extend several tasks of conventional modules (e.g. layout planning and planning of technical building services), because interactions among these tasks are important for the overall green factory performance.

\subsection{Conventional Planning Modules from Green Perspective}

Planning modules are based on a sum of tasks that is necessary to ensure an overall green factory and integrate supporting tools into the proceeding. The factory planning tasks vary between different planning approaches, for Green Factory Planning several conventional modules were identified as considerable, see [11], [12] and [13]. For example:

- Target Definition and Production Scenario Generation

- Process Planning, Machine Selection and Capacity Planning

- Material Flow Planning, Transport and Production Systems Planning

- Information Planning and Worker Planning

- Area and Layout Planning

- Building Planning and Technical Build Service Planning

For every module, a variety of methods and tools exists for the disciplines dealing with the tasks to perform them. Traditionally, activities are performed nearly independently apart from the fact that information generated in earlier tasks (e.g. process and machine planning) is used from other disciplines in later tasks. With that approach, a lot of effort is required to adjust outcomes of different planning modules and generate an overall factory view. Locally optimized factory items are the result. The modular green factory planning process instead needs to take the integrated green perspective on the overall factory into account and perform modules differently when they are relevant for green performance instead.

Every planning task and module was analyzed regarding green aspects that are not covered sufficiently in the existing modules. For every activity were aspects identified, that allow an influence on the green performance of the factory part that is planned. This can be aspects that are already considered in the methods and tools for the planning module (e.g. takt time), but get another dimension when environmental impacts are considered. Beyond that, aspects like the interaction between technical building services, building and production are not appropriately considered during the planning activity so they need to be included or emphasized. Table 1 gives an overview of some planning modules with additional aspects in terms of 'green' and the aspects, where 'green' has to be included as relevant performance driver.

Criteria that are considered in the established planning modules are still relevant, but might become less important depending on the green planning case. Methods and tools that support the work within the modules need to ensure, that 'green' as well as conventional aspects are covered, otherwise green factors planning will be just a 
theoretical concept. To make this possible, established criteria with no influence on 'green' (not mentioned in table 1) could be methodically linked to the green aspects.

Table 1. Excerpt of planning modules and additional criteria for 'green'

\begin{tabular}{|c|c|c|c|c|c|c|c|}
\hline & \multicolumn{7}{|c|}{ Planning Modules } \\
\hline & $\begin{array}{l}\text { Target Definition } \\
\text { and Production } \\
\text { Scenario } \\
\text { Generation }\end{array}$ & Process Planning & $\begin{array}{l}\text { Machine } \\
\text { Selection and } \\
\text { Capacity } \\
\text { Planning }\end{array}$ & $\begin{array}{c}\text { Material Flow } \\
\text { Planning and } \\
\text { Transport } \\
\text { Systems Planning }\end{array}$ & $\begin{array}{r}\text { Information and } \\
\text { Worker Planning }\end{array}$ & $\begin{array}{c}\text { Area and Layout } \\
\text { Planning }\end{array}$ & \begin{tabular}{|c} 
Building and \\
Technical \\
Building Servies \\
Planning
\end{tabular} \\
\hline \multirow{6}{*}{ 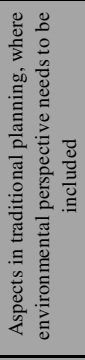 } & $\begin{array}{c}\text { Product } \\
\text { Requirements } \\
\text { and quantities } \\
\end{array}$ & $\begin{array}{c}\text { Production } \\
\text { sequence } \\
\text { planning } \\
\end{array}$ & $\begin{array}{c}\text { Degree of } \\
\text { automization }\end{array}$ & Takt time & $\mid \begin{array}{c}\text { Manufacturing IT } \\
\text { Systems }\end{array}$ & dimensions & building design \\
\hline & Make or Buy & $\begin{array}{l}\text { Technology } \\
\text { Trends }\end{array}$ & Investment Cost & \begin{tabular}{|c|} 
transport \\
(volume; -ability)
\end{tabular} & $\begin{array}{c}\text { Production } \\
\text { control }\end{array}$ & $\begin{array}{l}\text { infrastructure; } \\
\text { storage areas }\end{array}$ & building materials \\
\hline & $\begin{array}{c}\text { Motivation and } \\
\text { vision }\end{array}$ & Cost, quality & Supplier selection & material flow & & $\begin{array}{c}\text { material and } \\
\text { resource supply }\end{array}$ & windows; doors \\
\hline & Planning Targets & Usability & $\begin{array}{c}\text { product } \\
\text { specificiations }\end{array}$ & $\begin{array}{c}\text { hub/dock } \\
\text { concept }\end{array}$ & & Lean production & dimensions \\
\hline & $\begin{array}{l}\text { Risks and } \\
\text { opportunities }\end{array}$ & & & $\begin{array}{l}\text { means of } \\
\text { transportation }\end{array}$ & & & tubes and grids \\
\hline & $\begin{array}{c}\text { Project } \\
\text { organization }\end{array}$ & & & $\begin{array}{c}\text { Production } \\
\text { planning }\end{array}$ & & & HVAC \\
\hline \multirow{6}{*}{ 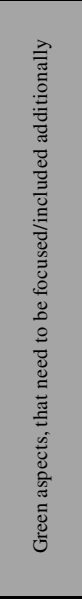 } & $\begin{array}{c}\text { Environmental } \\
\text { boundaries } \\
\text { (regulations, } \\
\text { public pressure/ } \\
\text { focus) }\end{array}$ & $\begin{array}{c}\text { Energy carriers } \\
\text { and } \\
\text { environmental } \\
\text { impacts (e.g. } \\
\text { emissions) }\end{array}$ & TCO, LCA & $\begin{array}{c}\text { Energy/ Building/ } \\
\text { TBS interactions }\end{array}$ & Green Awareness & $\begin{array}{c}\text { EHS (Fire } \\
\text { protection) / } \\
\text { Environmental } \\
\text { Imact zones } \\
\text { (AOE storage) }\end{array}$ & $\begin{array}{c}\text { centralised / } \\
\text { decentralised } \\
\text { (dependant } / \text { indep } \\
\text { endant from } \\
\text { machines) }\end{array}$ \\
\hline & $\begin{array}{c}\text { Green Targets } \\
\text { and Strategy }\end{array}$ & $\begin{array}{c}\text { (energy) } \\
\text { generation and } \\
\text { consumption }\end{array}$ & $\begin{array}{c}\text { equipment } \\
\text { components and } \\
\text { operationa } \\
\text { parameters }\end{array}$ & $\begin{array}{c}\text { Green } \\
\text { transportation } \\
\text { ideas }\end{array}$ & Green IT & $\begin{array}{l}\text { interactions of } \\
\text { TBS, Building, } \\
\text { transport and } \\
\text { Production line }\end{array}$ & $\begin{array}{c}\text { supply and } \\
\text { disposal areas } \\
\text { and infrastructure }\end{array}$ \\
\hline & $\begin{array}{l}\text { Concept for } \\
\text { Energy } \\
\text { Management }\end{array}$ & information flow & materials & $\begin{array}{c}\text { Sensors }+ \\
\text { Controls; } \\
\text { Metering concept }\end{array}$ & $\begin{array}{l}\text { Energy (Data) } \\
\text { Management }\end{array}$ & zoning & $\begin{array}{c}\text { on-site } \\
\text { generation, re- } \\
\text { use of energy, } \\
\text { integration of } \\
\text { renewables } \\
\end{array}$ \\
\hline & $\begin{array}{c}\text { Energy data } \\
\text { gathering }\end{array}$ & $\begin{array}{l}\text { Recycling and } \\
\text { waste } \\
\text { management }\end{array}$ & $\begin{array}{l}\text { Energy supply } \\
\text { concepts }\end{array}$ & load curves & & $\begin{array}{l}\text { area usage } \\
\text { efficiency }\end{array}$ & $\begin{array}{l}\text { (roof) shape, } \\
\text { orientation }\end{array}$ \\
\hline & $\begin{array}{c}\text { Highest impact } \\
\text { drivers, selection } \\
\text { of priorities }\end{array}$ & $\begin{array}{c}\text { Environment and } \\
\text { building } \\
\text { requirements }\end{array}$ & $\begin{array}{l}\text { dimension/ } \\
\text { capacities }\end{array}$ & $\begin{array}{c}\text { drive and speed } \\
\text { of transport }\end{array}$ & & & $\begin{array}{l}\text { Green building } \\
\text { guidelines }\end{array}$ \\
\hline & & $\begin{array}{c}\text { energy mix and } \\
\text { energy cost }\end{array}$ & & & & & $\begin{array}{c}\text { Insulation, heat } \\
\text { emissions }\end{array}$ \\
\hline
\end{tabular}

\subsection{Green Planning Modules}

From this analysis, green modules can be generated in three ways: First, they can be additional tasks that are not covered at the moment. These tasks become important, because factory elements might have major importance for the green factory, but they are not explicitly planned during factory planning in established approaches. An example would be a module for Energy Supply Planning that deals with the challenges of integrating renewable energies, security of energy supplies and on-site generation.

Second, some tasks have to be combined to ensure the interactions among factory entities for the purpose of green modules. Green modules are described based on the comparison of traditional method and tools with additional interactions and influences in terms of 'green'. These additional aspects of factory planning tasks result in new modules and requirements for supporting tools, because energy-related information 
has to be included, processed and evaluated in an integrated way. The difference between established modules (see [12] and [13]) and these green planning modules is the degree of information to be processed and the consideration of additional aspects.

Layout Planning in terms of 'green' has to be done not just in consideration of machine area use, storage requirements and transport ways but also considering zones (e.g. temperature, compressed air supply, lighting) with its interactions to building and technical building services. In the layout, machine dimensions are carefully considered, causing district heating or ventilation during operations. So the dimensioning and capacities of machine influence energy efficiency of the overall factory over its interactions with the layout. Therefore, more experts from different areas have to participate in terms of 'green' and green layout planning has to be interactive, communicative and visually representative considering additional influences. Planning methods like IntuPlan [14] or planning tables are not prepared for these requirements.

The third possibility for green modules is the integration of green aspects within the methods and tools of established modules. If the tasks and activities have no major connection to the performance of other modules (considering the total factory) it is sufficient to slightly adjust the planning module to ensure the relevance of green aspects. Taken the target definition as example, requirements have to be analyzed and the planning targets need to be defined as established, adding the environmental aspects to the methods and tools. As already described above, clear goals for the green factory have to be defined and linked to the features of the factory to identify the green planning modules. Nevertheless the conventional methods and outcomes are still relevant, so target planning changes to green target planning by extending the existing modules with the green aspects.

To make full use of the green modules in Green Factory Planning the input-output relations, the information environment and the method need to be clearly defined and described in a standardized profile. Especially the data processing and information generation has to coordinated, so that new conflicts that might appear (e.g. between lean - fast transport systems - and 'green' - energy efficient transport) can be solved with the overall factory competitiveness in mind.

\section{Conclusion and Outlook}

The paper described an approach for Green Factory Planning that is adaptable to specific cases and includes research results on green methods and tools. The approach is modular to pick the green planning modules that contribute the most to the green factory vision based on a mandatory target definition method. The additional aspects of green panning modules have been analyzed, described and the three possibilities to generate green planning modules presented.

Further research is required to ensure that all additional criteria are considered in the green modules. Some tools and methods have to be developed or detailed, to establish a common planning language among different disciplines involved in the planning. In addition, the flexible combination of green modules and conventional 
modules to a comprehensive planning process that integrates the green factory vision and the framework has to be detailed and reviewed within industry cases.

Further methods from academia could be included to address some challenges that occur due to the additional green aspects. For this, collaboration among the $\mathrm{EMC}^{2}$-Factory consortium and the research communities is pursued. Green planning modules can be changed or adopted easily, because they are well-defined and encapsulated from each other, but linked over input-output information.

Acknowledgements. This research is partially funded by the European Commission in the $7^{\text {th }}$ Framework research project EMC2-Factory (www.emc2-factory.eu).

\section{References}

1. Brundtlandt Comission, Our Common Future. United Nations World Commission on Environment and Development (WCED). Oxford University Press, Oxford (1987)

2. World Business Council of Sustainable Development (WBCSD), Changing Course: A Global Business Perspective on Development and the Environment. MIT Press, Cambridge (1992)

3. Hart, S.L.: How green production might sustain the world. Northwestern Environmental Journal 10, 4-14 (1994)

4. Müller, E., Engelmann, J., Löffler, T., Strauch, J.: Energieeffiziente Fabriken planen und betreiben. Springer, Berlin (2009)

5. Verein Deutscher Ingenieure, VDI5200:2009: Factory Planning - planning procedures. Beuth Verlag, Berlin (2009)

6. Wirth, S., Schenk, M., Müller, E.: Fabrikarten, Fabriktypen und ihre Entwicklungsetappen. ZWF Zeitschrift für Wirtschaftlichen Fabrikbetrieb 106(11), 799-802 (2011)

7. Bergholz, M.-A.: Objektorientierte Fabrikplanung. Shaker, Aachen (2005)

8. Chen, D., Heyer, S., Seliger, G., Kjellberg, T.: Integrating sustainability within the factory planning process. Paper presented at the 62nd CIRP General Assembly, Hongkong, China, August 19-25 (2012)

9. Hennersdorf, S., Dombrowski, U.: Algorithm for Choosing Factory Planning Methods and Tools. In: Katalinic, B. (ed.) DAAAM International Scientific Book, pp. 45-52. DAAAM International, Vienna (2009)

10. Müller, F., Cannata, A., Okur, A., Thiede, S., Herrmann, C.: Classification of factories from a green perspective: initial guidance and drivers for 'Green Factory Planning'. Paper presented at the 10th Global Conference of Sustainable Manufacturing, Istanbul, Turkey, October 31-November 02 (2012)

11. Felix, H.: Unternehmens- und Fabrikplanung: Planungsprozesse, Leistungen und Beziehungen. Fachbuchverlag Leipzig, Leipzig (1998)

12. Chen, D.: Information Management for the factory planning process. Dissertation, KTH Stockholm, Sweden (2009)

13. Nöcker, J.C.: Zustandsbasierte Fabrikplanung. Apprimus Verlag, Aachen (2012)

14. Tröger, S., Berndt, M., Müller, F., Jentsch, D., Riedel, R., Müller, E.: 3D-Kommunikation in der Fabrikplanung. ZWF Zeitschrift für Wirtschaftlichen Fabrikbetrieb 107(9), 632-636 (2012) 